\title{
THE HARPER GOVERNMENT, THE ABORIGINAL RIGHT TO SELF-DETERMINATION, AND THE INDIAN ACT OF 1876
}

\author{
KRISTÝNA ONDERKOVÁ
}

\begin{abstract}
A debate on the reform of the frequently criticized Indian Act of 1876 - the basic law governing the rights and responsibilities of First Nations and their special status within Canada - is getting more intense with the ongoing socio-economic problems of Aboriginal peoples. Whereas the federal government emphasizes self-sufficiency and financial responsibility, First Nations require the assertion of their constitutional rights to self-determination and self-government in any future reform. This paper examines various proposals to reform the Indian Act and their potential effect on the status of First Nations. In particular, it focuses on Aboriginal policy stances of the Harper Government and the First Nations' reaction to the federal government's approach. The author concludes by arguing that any effort to change the current situation will run into problems because of the discrepancy of ideas on how to implement the reform of the Indian Act and how to enforce the right to self-determination.
\end{abstract}

Keywords: Canada, First Nations, Indian Act of 1876, right to self-determination, Idle No More DOI: $10.14712 / 23363231.2016 .3$

\section{Introduction}

The debate around the controversial Indian Act of 1876, which - along with the Canadian Constitution of 1982 - provides the basis for the rights of one of the largest groups of Indigenous peoples in Canada, the First Nations, has been going on since its approval. However, resounding calls for the act's amendment or even replacement have been recently issued both by the country's political elites and First Nations' leadership.

Since 1969 when the White Paper, a first major federal attempt to replace the Indian Act, was presented, successive governments have more or less continued 
to endorse a special status for Aboriginal peoples in Canada. Nevertheless, the substantial difference in living standards of Native and non-Native Canadians has not diminished, and the socio-economic problems of many Aboriginal communities, such as bad housing situation, alcoholism, domestic violence, sexual abuse, suicides, unemployment, poverty and drug addiction, remain. ${ }^{1}$ Canadian governments have tried to solve the issue and find new ways to improve the conditions of Aboriginal peoples but they have failed to achieve amelioration of the Native peoples' situation.

In contrast with the previous Liberal governments' approach of "equal negotiation" - an approach towards Native peoples consisting in negotiations and dialogue between the federal government and Aboriginal communities -, the Conservative legislative framework has adopted a neoliberal way of dealing with the issue. The Conservative Government calls for responsibility and self-sufficiency for Indigenous peoples. It seeks to boost their economic activity and reduce Aboriginal dependence on federal funding and social benefits.

The Idle No More (INM) protest movement founded in 2012 in reaction to some of the federal government's laws pertaining to Indigenous peoples promotes the Aboriginal rights to self-determination and self-government, sustainable development, and environmental protection that are inextricably linked with Indigenous identity. Both the First Nations communities and the federal government thus appear to aim for self-governance of Indigenous peoples; however, the ways by which these two groups want to accomplish such a goal vary considerably.

The aim of the article is to present the Conservative Government's and First Nations' ideas on how to reform the Indian Act of 1876 in order to enforce the Aboriginal rights to self-determination and self-government, and more precisely, to examine the extent to which the two ways of how to achieve Indigenous self-government differ.

The first part will provide a theoretical framework introducing and comparing the main approaches that deal with the status of Native peoples - the Hawthorn Report's and Alan Cairn's concept of "differentiated citizenship," in contrast to the White Paper and Thomas Flanagan's philosophy of "undifferentiated citizenship" - with regard to the question of the Aboriginal rights to self-determination and of self-government. The Idle No More movement's statements and stances on the issues of self-determination and self-government on the one hand, and the

1 Éric Gourdeau, "Les autochtones et le Québec," in Le Québec aujourd’hui: Identité, société et culture, ed. Marie-Christine Weidmann-Koop (Saint-Nicolas: Les Presses de l'Université Laval, 2003), 137-38. 
rhetoric and reform proposals of the Conservative Government on the other hand, will be examined in the second part of the article.

\section{Aboriginal Peoples, First Nations, and the Indian Act of 1876}

"Aboriginal peoples," "Native peoples," and "Indigenous peoples" are all common terms used for the descendants of the first inhabitants of Canada who most probably came to the continent across the Bering Strait about 12,000 years ago. ${ }^{2}$ Section 35 (1) of the Canadian Constitution Act of 1982 reads that the existing Aboriginal and treaty rights of the Aboriginal peoples of Canada are recognized and affirmed. Section 35 (2) explicitly recognizes the rights of three Aboriginal groups: the Indians (First Nations), the Métis (the half-caste descendants of Aboriginal peoples and European settlers) and the Inuit (Eskimos). ${ }^{3}$

This constitutional framework was groundbreaking, since the Constitution Act of 1867, also known as the British North America Act (specifically its Section 91 [24]), had established that the federal government had legislative jurisdiction over Indians and lands reserved for Indians, which had enabled the federal government to unilaterally impose the Indian Act on Aboriginal peoples. ${ }^{4}$ The Constitution Act of 1982 thus constitutionally enshrined Indigenous rights for the first time in Canadian history.

The Indian Act of 1876 remains the basic legal anchor of First Nations' rights and responsibilities in the current Canadian legal system. It intervenes in the economic, social, and cultural aspects of the lives of First Nations. It covers both private and public questions such as Indian Status and band membership, property rights, housing, inheritance, administration of reserves, political rights and freedoms, elections, taxation, Indian lands and resources, and education. ${ }^{5}$

The original intention of the legislation was to absorb Indians into the rest of Canadian society. Indians were to be "civilized" and Christianized, and their traditional community structures, ceremonies and rituals were to be eliminated. The main purpose was assimilation; ${ }^{6}$ however, some provisions of the Indian Act were

2 Olive Patricia Dickason, Canada's First Nations: A History of Founding Peoples from Earlier Times (Toronto: University of Oklahoma Press, 1992), 21.

3 The Constitution Act, 1982, Schedule B to the Canada Act 1982 (UK), c 11, http://laws-lois.justice .gc.ca/eng/Const/FullText.html.

4 The Constitution Act, 1867, 30 \& 31 Vict, c 3, http://canlii.ca/t/ldsw.

5 Indian Act, R.S.C. 1985. c. I-5. http://laws-lois.justice.gc.ca/eng/acts/I-5/page-1.html.

6 Carrie Bourassa and Ian Peach, Reconceiving Notions of Aboriginal Identity. Research paper for the Institute on Governance (November 2009), 4, http://iog.ca/wp-content/uploads/2013/01 /November2009_Reconceiving-Aboriginal-Identity.pdf. 
designed to protect First Nations, since the government was obliged by treaties to protect Indian interests and lands. Nevertheless, the Indian Act eventually proved to be little more than a colonial instrument for subordination of First Nations since it essentially deprived them of self-governance. ${ }^{7}$

Many First Nations have an ambiguous relationship towards the Indian Act. They denounce its paternalism, but they are reluctant to renounce some of its protections (one of the most advantageous of such protections is Section 87 of the Indian Act, which exempts Status Indians from provincial and federal taxation). ${ }^{8}$ Without these protections, the risk that First Nations were assimilated into Canadian non-Native society would increase.

\section{Citizens Plus or "Undifferentiated" Citizens?}

The United Nations Declaration on the Rights of Indigenous Peoples affirms the importance of the right to self-determination of all peoples "by virtue of which they freely determine their political status and freely pursue their economic, social and cultural development." In its Articles 3 and 4, the UNDRIP states that Indigenous peoples have the right to self-determination, and in exercising their right to self-determination, Aboriginal peoples are endowed with the "right to autonomy or self-government" in matters relating to their internal and local affairs, as well as ways and means for financing their autonomous functions. ${ }^{10}$

The inherent right to self-government is recognized as an existing Aboriginal right under Section 35 of the Constitution Act of $1982 .{ }^{11}$ It is based on the belief that Indigenous peoples have the right enforceable through the courts to govern themselves in internal matters concerning their communities due to their unique identities, cultures, traditions and institutions. ${ }^{12}$ The right to self-government includes jurisdiction over the definition of governance structures, (band)

${ }^{7}$ Duncan Ivison, Political Theory and the Rights of Indigenous Peoples (Cambridge: Cambridge University Press, 2000), 118.

8 Isabelle Montpetit, "Background: The Indian Act," CBC News, May 30, 2012, http://www.cbc.ca /news/canada/background-the-indian-act-1.1056988.

9 United Nations Declaration on the Rights of Indigenous Peoples. Resolution adopted by the UN General Assembly, October 2, 2007, http://www.un.org/esa/socdev/unpfii/documents/DRIPS_en.pdf.

10 United Nations Declaration on the Rights of Indigenous Peoples.

11 Although recognition of the right to self-government is not explicitly stated in Section 35, it is interpreted in this manner. See Aboriginal Affairs and Northern Development Canada, The Government of Canada's Approach to Implementation of the Inherent Right and the Negotiation of Aboriginal Self-Government, 2010, https://www.aadnc-aandc.gc.ca/eng/1100100031843/1100100031844\#esga.

12 Aboriginal Affairs and Northern Development Canada, The Government of Canada's Approach. 
membership in First Nations, family matters, education, health services, and ownership of land. ${ }^{13}$

In the following part, I will discuss the concepts that are inextricably linked with the questions of the legal anchoring of Aboriginal peoples in Canada, and with their rights to self-determination and self-government, developed by scholars Thomas Flanagan and Alan Cairns. I will analyze and compare their theoretical approaches to the Aboriginal question in order to see the issue from very different perspectives. The concept of "undifferentiated citizenship" advocated by Flanagan was partly influenced by the Trudeau Government's White Paper, and it partly forms the ideological basis for the policy of the Harper administration. ${ }^{14}$ Cairns' concept of "citizens plus" is based on the recommendations of the Hawthorn Report.

In 1966-67, Harry B. Hawthorn published A Survey of the Contemporary Indians of Canada: Economic, Political, Educational Needs and Policies, also known as the Hawthorn Report. This was the first impetus for a significant reform of the Indian Act since its adoption because it drew attention to the poor conditions of Aboriginal peoples in Canada. ${ }^{15}$ Hawthorn argued that the disadvantaged situation of Aboriginal communities stemmed from ill-designed government policies. Additionally, the Report supported the idea that since Indigenous peoples had inhabited the American continent before the arrival of Europeans, who subsequently treated them as inferior and subordinate, a positive recognition of Status Indians as so called "citizens plus," would counterbalance their historical mistreatment. ${ }^{16}$ The term "citizens plus," which was at the time very positively received by Indian groups, ${ }^{17}$ was subsequently adopted into Indigenous affairs scholarship by Canadian political scientist Alan Cairns.

The Hawthorn Report launched consultations between the federal government and First Nations' leadership across Canada in order to amend the Indian Act, and the issue of self-determination and self-government of Indigenous

${ }^{13}$ James Anaya, The Situation of Indigenous Peoples in Canada. Report of the Special Rapporteur on the rights of Indigenous peoples. United Nations, General Assembly, Human Rights Council, July 4, 2014, 6, http://www.ohchr.org/Documents/Issues/IPeoples/SR/A.HRC.27.52.Add.2-MissionCanada_AUV.pdf.

${ }^{14}$ Marci McDonald, "The Man behind Stephen Harper," The Walrus, October 2004, http://thewalrus .ca/the-man-behind-stephen-harper/.

15 Harry B. Hawthorn, ed., A Survey of the Contemporary Indians of Canada: A Report on Economic, Political, Educational Needs and Policies, Indian Affairs Branch, October, 1967, 5, https://www.aadnc -aandc.gc.ca/DAM/DAM-INTER-HQ/STAGING/texte-text/ai-arp-ls-pubs-sci3_1326997109567 _eng.pdf.

16 Hawthorn, A Survey of the Contemporary Indians, 7.

17 Alan Cairns, Citizens Plus: Aboriginal Peoples and the Canadian State (Vancouver: UBC Press, 2000), 164. 
peoples came to the foreground. In 1969, the Government of Pierre Elliott Trudeau proposed the Statement of the Government of Canada on Indian Policy, known as the White Paper. The drafters of the White Paper agreed with the Hawthorn Report's conclusion that the system of separate institutions and the special legal status of First Nations created by the Indian Act were ineffective, and contributed to their lagging behind the non-Aboriginal Canadians in well-being. However, the proposed means of reform in the Hawthorn Report and the White Paper substantially differed.

The Trudeau Government's policy towards Aboriginal peoples based on a Western liberal mindset ${ }^{18}$ can be interpreted in the light of the U.S. Civil Rights Movement, especially the emancipation of Afro-Americans in the 1960s, and the rhetoric of the U.S. Supreme Court ruling in Brown v. Board of Education of 1954. It is evidenced by the White Paper's statement "separate but equal services do not provide equal treatment." 19 The Report suggested, inter alia, abolishing the special status of Indigenous peoples in order to fully integrate them in Canadian society. Furthermore, it called for revoking the Indian Act and terminating the Department of Indian Affairs and Northern Development. ${ }^{20}$

Most First Nations opposed the government's proposal because it would have meant the end of their special legal status and their right to self-determination and self-government would be suppressed. The rhetoric of the proposal was criticized for being peremptory and unyielding. ${ }^{21}$ Citizens Plus, an Indian response to the White Paper, also called the Red Paper, was published in 1970 by the Indian Association of Alberta, with the support of the National Indian Brotherhood (NIB). The Red Paper partly adopted the Hawthorn Report's concepts. In particular, it suggested that the constitutional basis of Indian rights and their legal status should be preserved, because only the First Nations themselves can renegotiate them. ${ }^{22}$ In the same year Trudeau withdrew his proposal.

18 Menno Boldt, Surviving as Indians (Toronto: University of Toronto Press, 1993), 21.

${ }^{19}$ Hamar Foster, Heather Raven and Jeremy Webber, eds., Let Right Be Done: Aboriginal Title, the Calder Case, and the Future of Indigenous Rights (Seattle: University of Washington Press, 2008), 101.

20 Statement of the Government of Canada on Indian Policy, 1969. Paper presented to the First Session of the Twenty-eighth Parliament by the Honorable Jean Chrétien, Minister of Indian Affairs and Northern Development, http://www.aadnc-aandc.gc.ca/eng/1100100010189/1100100010191.

21 Susana Mas, "Trudeau Liberals Woo High-Profile Aboriginal Candidates Ahead of 2015," CBC News, September 29, 2014, http://www.cbc.ca/news/politics/trudeau-liberals-woo-high-profile-aboriginal -candidates-ahead-of-2015-1.2764945.

22 Indian Chiefs of Alberta, Citizens Plus. A Presentation by the Indian Chiefs of Alberta to Right Honorable P. E.Trudeau, Prime Minister and the Government of Canada, June 1970, Aboriginal Policy Studies vol. 1, no. 2 (2011): 189-90, http://ejournals.library.ualberta.ca/index.php/aps/article /download/11690/8926. 
The Erasmus-Dussault Report of the Royal Commission on Aboriginal Peoples (RCAP) was put together in order to "help restore justice to the relationship between Aboriginal and non-Aboriginal people in Canada, and to propose practical solutions to stubborn problems." 23 The five-volume, 4,000-page Report with its 440 recommendations covered an extensive range of issues. It proposed to implement radical measures in order to replace the old colonial and paternalistic governmental approach towards Native peoples with an approach based on partnership. It endorsed changes such as the reform of the Department of Indian Affairs and Northern Development, the creation of an Aboriginal parliament, or a system of dual citizenship. ${ }^{24}$

The critics of the RCAP stressed the Report's disproportionate emphasis on self-government and, inversely, its omission of Aboriginal peoples' representation in non-Aboriginal bodies. The recommendations of the Erasmus-Dussault Report did not fit into mainstream Canadian historical tradition and political context. On the other side, the Assembly of First Nations (AFN) criticized it for its moderation, but later blamed the Liberal government for failing to put into practice the Report's recommendations. ${ }^{25}$

Thomas Flanagan, an American-born conservative political scientist and a former advisor to Stephen Harper, has been one of the leading critics of the RCAP's way of promoting Aboriginal self-government. According to his critical approach, a greater political autonomy of Indigenous peoples is counterproductive because it places them outside the economic realities of today's world. Flanagan, who had a significant impact on shaping Harper's policy towards Indigenous peoples, advocates the concept of "undifferentiated citizenship." This contradicts the Report of the RCAP, as well as the concept of "citizens plus" promoted by the Hawthorn Report and by Alan Cairns.

According to Flanagan, "in order to become self-supporting and get beyond the social pathologies that are ruining their communities, Aboriginal peoples need to acquire the skills and attitudes that bring success in a liberal society, political democracy, and market based economy. Call it assimilation, call it integration, call

23 Aboriginal Affairs and Northern Development Canada, Highlights from the Report of the Royal Commission on Aboriginal Peoples, 2014, http://www.aadnc-aandc.gc.ca/eng/1100100014597 /1100100014637.

24 Royal Commission Report on Aboriginal Peoples, Government of Canada Web Archive, Library and Archives Canada, 1996, http://www.collectionscanada.gc.ca/webarchives/20071115053257/http:// www.ainc-inac.gc.ca/ch/rcap/sg/sgmm_e.html.

25 Cairns, Citizens Plus, 141, 157. The Assembly of First Nations is an official organization of First Nations, in which each band is represented by its chief. The AFN' mission is to protect and promote the Indigenous rights and interests. 
it adaptation, call it whatever you want: it has to happen." 26 Instead of the enforcement of the rights to self-determination and self-government, Flanagan's concept of "undifferentiated citizenship" suggests a return to the policy of voluntary assimilation of Indigenous peoples with an emphasis on their economic self-sufficiency. This implies that economic development is not possible without the normalization of political rights and without the reform of the Indian Act which effectively keeps Indigenous peoples in economic isolation.

Alan Cairns believes that Indigenous peoples differ from non-Aboriginal Canadians, but not completely, because of their common living space. ${ }^{27} \mathrm{He}$ argues that the future of Aboriginal peoples lies "inside" the Canadian federation. Unlike Flanagan, however, Cairns suggests that Aboriginal peoples should be understood as "citizens plus" - Canadians with special rights; "by 'plus' we referred to ongoing entitlements, some of which flowed from existing treaties while others were to be worked out in the political processes of the future, which would identify the Indian peoples as deserving possessors of an additional category of rights based on historical priority." 28 The concept of "citizens plus" thus combines the recognition of the distinctiveness of Indigenous peoples with their inclusion in Canadian society. ${ }^{29}$

\section{The Right to Self-Government and Self-Government Agreements}

In the last decade of the twentieth century, an attempt to negotiate a constitutional anchoring of the Indigenous peoples' right to self-government was included in the proposed Charlottetown Accord. The Charlottetown Accord suggested amending the Constitution of 1982 and enacting a law allowing for guaranteed representation of Indigenous peoples in the Canadian House of Commons and Senate. Representatives of Aboriginal peoples were to get a say in the selection of Supreme Court judges and in the debates over the future constitutional amendments. According to the Charlottetown Accord, they were to be consulted when discussing legislation that might directly affect them. ${ }^{30}$ The proposed agreement was, however, rejected in a general referendum in October 1992.

26 Thomas Flanagan, First Nations? Second Thoughts (Cambridge: Cambridge University Press, 2000), 196.

27 Cairns, Citizens Plus, 5.

28 Ibid., 12.

${ }^{29}$ Ibid., 90-91.

30 Consensus Report on the Constitution, Charlottetown, August 28, 1992, https://www.saic.gouv .qc.ca/publications/Positions/Part3/Document27_en.pdf. 
Will Kymlicka, one of the most eminent contemporary Canadian political philosophers, believes the logic behind the idea of Aboriginal peoples' right to self-government included in the proposed Charlottetown Accord and supported by the RCAP is the principle of representation and power sharing. According to this liberal perspective, Indigenous peoples should not be obliged to obey a constitution drawn up by their historical "conquerors," which they did not have the chance to influence. They should not be governed by bodies formed of non-Aboriginal peoples only. They should not be expected to obey laws passed by non-Aboriginal legislators and they should not be answerable to courts where Aboriginal peoples are not represented. ${ }^{31}$

First, self-government could, as Alan Cairns claims, serve Native communities as a means of equalization and strengthen their position in relation to the majority population. First Nations could thus decide themselves what to adopt from non-Aboriginal society and what and how to preserve in their own traditions. ${ }^{32}$ Second, the idea that "responsibility begins at home," which is also emphasized by the Harper Government, means that self-government would transfer the responsibility over First Nations' actions, their advancement or deterioration, to themselves. It would ease the burden of the federal government, which could no longer be blamed for the poor socio-economic situation of First Nations. ${ }^{33}$

However, specific circumstances must be taken into account when considering the possibility of self-governed First Nations in Canada. They form neither a coherent nor a homogeneous group. They are dispersed across all Canadian provinces. ${ }^{34}$ Indian bands vary both in the size of their territory and the number of their members. Moreover, different First Nations have different cultural traditions, historical experience, and ways of life. Taking into account all these differences, pan-Indian self-government of First Nations would be in practice very difficult. The self-government of individual First Nations would be an option; however, it would also mean enormous political fragmentation of Canada.

One could also argue that there is no need for pan-Indian self-government of First Nations because band councils, larger groupings called tribal and chiefs' councils, and the Assembly of First Nations are able to adequately protect and promote the interests of First Nations. Furthermore, some groups such as the Cree, the Sechelt Indian Band, or the Yukon First Nations have already obtained substantial competencies, such as greater control and law-making authority over

31 Will Kymlicka, Multicultural Citizenship (Oxford: Oxford University Press, 1995), 169.

32 Cairns, Citizens Plus, 111.

33 Ibid.

${ }^{34}$ Kymlicka, Multicultural Citizens, 29. 
a comprehensive range of jurisdictions, including health, education or lands, ${ }^{35}$ and the corresponding self-government arrangements were signed between the federal government and these groups. On the other hand, band council resolutions are still only effective when approved by the Department of Aboriginal Affairs and Northern Development under the Indian Act. ${ }^{36}$

In 1983, Canada's House of Commons set up a parliamentary committee known as the Penner Committee to inquire into matters of Aboriginal self-government. In its report, the Penner Committee acknowledged that the right to self-government was inherent to all First Nations as protected by the Constitution. In 1995, the Liberal government of Jean Chrétien introduced so called Inherent Right Policy in order to negotiate practical arrangements to implement Native self-government through new self-government agreements (SGA). These agreements are negotiated with the federal government to enhance greater Aboriginal control and law-making authority.

The self-government agreements do not fall under the Indian Act and enable First Nations to obtain the power to introduce and enact laws concerning their people, to tax, to provide for municipal planning, and to decide on lands and resources. Each First Nation community has its constitution containing the membership code, establishing governing bodies, and protecting the rights and freedoms of its members.

There have been 21 self-government agreements completed so far and other 90 agreements are currently under negotiation. ${ }^{37}$ However, these Indigenous governments have only limited law-making powers under the agreements; areas such as security or transport remain under federal jurisdiction. ${ }^{8}$ In addition, the process of submitting a proposal and negotiating an agreement is complicated and lasts for years or even decades. ${ }^{39}$

Moreover, Martin Papillon claims that the Conservative Government is moving away from the self-government agreements, and is increasingly pushing for

35 Cree-Naskapi (of Quebec) Act, S.C. 1984, c. 18, http://laws-lois.justice.gc.ca/eng/acts/C-45.7/; Sechelt Indian Band Self-Government Act, S.C. 1986, c. 27, http://laws-lois.justice.gc.ca/eng/acts/S-6.6/; and Yukon First Nations Self-Government Act, S.C. 1994, c. 35, http://laws-lois.justice.gc.ca/eng /acts/Y-2.6/.

36 See Indian Act, art. 20, 24, 45, 49, 50, 54, 83, 86, 117 and 121.

37 Aboriginal Affairs and Northern Development Canada, Fact Sheet: Aboriginal Self-Government, 2014, https://www.aadnc-aandc.gc.ca/eng/1100100016293/1100100016294.

38 Aboriginal Self-Government, official website of Newfoundland and Labrador Heritage, http://www .heritage.nf.ca/law/aboriginal_self_gov.html.

39 Daniel Schwartz, "7 Questions about First Nations Accountability," CBC News, February 20, 2013, http://www.cbc.ca/news/canada/7-questions-about-first-nations-accountability-1.1331320. 
the terms "governance agreements" and "good governance." 40 These "governance agreements" represent a "form of Aboriginal, federal, and provincial partnership in the financing, development, and delivery of services, toward a common goal that is, to 'close the gap' between the social and economic conditions of Aboriginal peoples and other Canadians." 41 However, they also divert attention from the wider debate on the rights of Indigenous peoples, which form an integral part of their narrative, to economic sustainability and sector-specific agreements for the management of programs and services. ${ }^{42}$

Despite the recent developments related to the SGA, the Indian Act remains the prevailing legal regime in Aboriginal affairs. It does not permit the effective exercise of Aboriginal self-government and orders that almost all decisions made by First Nations, such as funding for reserve programs and infrastructure, changes in band by-laws, and the leasing of land, must seek the approval of the federal Minister of Aboriginal Affairs and Northern Development. In order for Indigenous peoples to exercise their right to self-determination and self-government, the current legislative settings must change.

Flanagan proposes three concrete reforms which should be carried out regarding the situation of Native peoples. First is better auditing, the creation of a professional corps of Aboriginal public servants and self-financing through taxation. He suggests that instead of the current large financial support from the federal government, First Nations should raise money from taxes. This possibility is already entrenched in Section 83 of the Indian Act, but as yet band councils have only used this power to tax non-Aboriginal people who own property on reserves. ${ }^{43}$ Second, the concentrated power of corrupt and inefficient band councils who have control over land, housing, education, employment, and welfare need to be split among multiple actors. Third, collective ownership has to be replaced by individual ownership in order to strengthen the economic activity of Aboriginal peoples. ${ }^{44}$

One of the problems of Flanagan's analyses lies in his categorical statements that sometimes resemble the theory of natural selection and social Darwinism. His view is very Eurocentric. Indigenous peoples do not necessarily perceive the influence of Western civilization as a step forward. Moreover, it is uncertain whether

\footnotetext{
40 Martin Papillon, "The Rise (and Fall?) of Aboriginal Self-Government," in Canadian Politics, 6th ed., ed. James Bickerton and Alain G. Gagnon (Toronto: University of Toronto Press, 2014), 127.

41 Ibid., 126.

42 Ibid., 114.

43 Flanagan, First Nations, 103.

${ }^{44}$ Ibid, 197-98.
} 
the principles of market based economy and private ownership would function for the benefit of First Nations communities if their land was broken up into individual pieces as Flanagan claims in the part of his book on the success of the Euro-Canadian civilization. ${ }^{45}$

Most importantly, Flanagan does not take into account that collective rights are considered by First Nations as their inherent right given to them by the Creator. This rather holistic belief forms an inseparable part of First Nations' very existence. In other words, Flanagan's arguments and propositions assume Western superiority while denying the principle of equal rights. This puts him in the colonial camp of reasoning - a camp which has been rejected by Aboriginal peoples, the Royal Commission on Aboriginal Peoples, as well as by the international community through the UNDRIP.

Alan Cairns refuses both the assimilationist paradigm advocated by Trudeau's White Paper and by Flanagan, and the more recent parallelism based on the idea of a completely distinct society of Aboriginal peoples within Canada, so prominent in the Report of the RCAP. The problem of Cairns' theory is that while he states that Native peoples should be integrated in Canadian society as "citizens plus," he does not explain how this would work in practice. He asserts that labels matter, ${ }^{46}$ which is certainly true, but the feasibility of a theory based almost entirely on the importance of labeling raises questions. Moreover, regrettably and in contrast to Flanagan, Cairns does not further examine what concrete steps or legislative reforms should be done to achieve this goal in order to deal with actual Aboriginal socio-economic problems.

The analysis of the two opposing concepts of how Aboriginal self-determination and self-government should be addressed reveals problematic aspects that prevent their effective application. Flanagan's suggestions favor "undifferentiated citizenship" which is incompatible with the gist of Aboriginal peoples' rights to self-determination and self-government. By contrast, Cairns' concept of "citizens plus" does include a special status for Indigenous peoples; however, it only provides a theoretical, not practical way to streamline assimilationist paradigm and parallelism in practice.

\footnotetext{
45 A parallel can be seen in what happened after the Native American land was unilaterally allotted to non-Native Americans by the US Government which is considered as an example of Michael Heller's "tragedy of the anticommons."

46 Cairns, Citizens Plus, 7.
} 


\section{Bill C-45 and the Right to "Free, Prior, and Informed Consent"}

Due to the pressing problems of Indigenous peoples, the large fiscal burden that they generate, and the pre-election commitment to streamline state financing, Stephen Harper and his party entered the 2006 election with a program of gradual amendment of legislation concerning Aboriginal peoples. This included a reform of the Indian Act, maximum financial efficiency of First Nations, and exploitation of natural resources on Indigenous territories.

The omnibus Bill C-45, passed into law on December 14, 2012, under the title Jobs and Growth Act, 2012, sparked a wave of protests that eventually led to the formation of Idle No More. First Nations, such as the Western Cree Tribal Council, opposed this legislation in particular because it affected their access to and control over fisheries, waterways, and land. ${ }^{47}$

Through Division XVIII of Bill C-45, the Navigable Waters Protection Act (NWPA) became the Navigation Protection Act (NPA), which removed a substantial number of lakes and streams from federal protection under the law. In total, only 3 oceans, 62 rivers, and 97 lakes listed under the so-called "Schedule 2" have remained protected. ${ }^{48}$ However, Canada has some 32,000 lakes and 2.25 million rivers. While previously the NWPA protected virtually $100 \%$ of the country's water bodies, ${ }^{49}$ the NPA no longer protects $99.7 \%$ of Canada's lakes and $99.9 \%$ of Canada's rivers. ${ }^{50}$

The federal government justified the amendment as being necessary to "facilitate trade and commerce by balancing the efficient movement of maritime traffic with the need to construct works (e.g. bridges) that might obstruct navigation, in order to encourage economic development."51 This legislation, which had not been discussed with First Nations, enabled the Harper Government to more easily carry out projects that threaten the environment, such as the Enbridge Northern Gateway Pipelines Project - a construction of a twin pipeline carrying tar sand

${ }^{47}$ Western Cree Tribal Council Press Release to Bill C-45, official website of the Western Cree Tribal Council, http://www.westerncree.ca/pdf/PRESS\%20RELEASE\%20C-45.pdf.

48 Hassan Arif, "How Harper's Neglect Suffocates Native Potential," The Huffington Post Canada, December 31, 2012, http://www.huffingtonpost.ca/hassan-arif/idle-no-more-environment_b_2387782.html.

49 Naomi Klein, This Changes Everything: Capitalism vs. The Climate (New York: Simon and Schuster, 2014), 381.

50 Derek Inman, Stefaan Smis and Dorothée Cambou, "We Will Remain Idle No More: The Shortcomings of Canada's 'Duty to Consult' Indigenous Peoples," Goettingen Journal of International Law 5, No. 1 (2013): 256.

51 Department of Finance Canada, Bill C-45 - 'Jobs and Growth Act, 2012' - Part 4, Ottawa, Canada, 2012, http://www.fin.gc.ca/pub/c45/4-eng.asp. 
carbon-intensive oil from western provinces to the Pacific Coast for overseas markets. Moreover, the implementation of these projects represents an intervention in the environment in which First Nations live. These water bodies and the nature that surrounds them form part of First Nations' identity and participation in decision making about them falls under their right to self-determination.

The other two controversial parts of this legislation are Division IV and VIII. One of the divisions amends the Fisheries Act so that fisheries, which have always been a traditional activity and privilege of Indigenous peoples, not captured within the definition of "Aboriginal," "commercial" or "recreational" fisheries, will no longer be protected under the Fisheries Act. The problem is that the definition of "Aboriginal" fisheries does not include all First Nations fisheries, which reduces the number of persons who have the right to fish based on "peace and friendship treaties." 52

The other division unilaterally amends the Indian Act in that it modifies the voting and approval procedures in relation to the proposed land designations. First Nations do not need a majority of eligible voters, but only a majority of voters gathered at a meeting or referendum, in order to decide whether reserve lands will be leased. Furthermore, the Minister of Aboriginal Affairs and Northern Development can call a meeting or referendum to consider land surrender from the band's territory. ${ }^{53}$ This may take control over land sales away from First Nations and result in a loss of Native land.

The Indian Act is the basic source of law for First Nations in Canada; thus, its amendment without proper consultation with their representatives highlights the Harper Government's little regard of Indigenous Canadians' right to self-determination and different perspective on the way of functioning of the Indigenous peoples' self-government. Moreover, the simplification of the voting procedure can facilitate access to land on reserves for non-Aboriginal outside operators. This can result in the land belonging to First Nations communities getting into the hands of non-Native entities, along with the profit from it, and thus actually worsen the economic situation of First Nations. Last but not least, it will also allow for ministerial interference in band decision making, which is a clear infringement of the First Nations' right to self-determination.

\footnotetext{
52 Assembly of First Nations States Concerns on Bill C-45 to Senate Standing Committee, official website of the Assembly of First Nations, November 27, 2012, http://www.afn.ca/index.php/en /news-media/latest-news/assembly-of-first-nations-states-concerns-on-bill-c-45-to-senate-stand.

${ }^{53}$ House of Commons, A Second Act to Implement Certain Provisions of the Budget Tabled in Parliament on March 29, 2012 and Other Measures, 1st Session, 41st Parliament, December 14, 2012, 203-6, 226-28, http://laws-lois.justice.gc.ca/PDF/2012_31.pdf.
} 
In R. v. Sparrow (1990), the Supreme Court of Canada (SCC) ruled on the constitutionality of federal fishing permits, and the banning of some methods of fishing. Fishing for salmon, which was affected by the regulations, played a key role in the cultural identity of the Musqueam First Nation of British Columbia. In the landmark decision, the SCC ruled in favor of the Musqueam First Nation. It argued that Section 35 (1) of the Constitution of Canada, 1982, protected practices that were integral to an Aboriginal community's distinctive culture. ${ }^{54}$ Furthermore, it laid out that policies and legislation, implemented by the federal government, restricting the exercise of a recognized and affirmed Aboriginal right, were required to be adequately consulted with the involved Aboriginal community. ${ }^{55}$ The government was now obligated to consult with First Nations about policies and legislation that directly affect them. This right to "free, prior, and informed consent" (FPIC) forms a part of the Aboriginal rights to self-determination and self-government. ${ }^{56}$

The concept of FPIC derives from the SCC's interpretation of the complex "fiduciary" relationship between the Crown and Canada's Aboriginal peoples, originating already with the Royal Proclamation of 1763. According to the Sparrow interpretation of the Section 35 (1), the Government is responsible for acting in a fiduciary way with respect to Indigenous peoples. ${ }^{57}$ Trust must be the first consideration in determining whether a governmental legislation or action can be justified. And it can be justified inter alia on the condition that the affected Aboriginal groups had been consulted..$^{58}$

The Harper Government's legislative proposals, particularly Bill C-45, are not congruent with Indigenous peoples' right to self-determination. As Michael Den Tandt aptly remarks, "No fundamental change in governance can or should happen without the consent of the governed." Hence, any prospective legislation replacing the Indian Act of 1876 ought to be written with the consent of and in consultation with First Nations if not by First Nations themselves. ${ }^{59}$ Clearly, this has not been the Conservative Government's course of action.

${ }^{54}$ R v. Sparrow, Supreme Court of Canada, 1990, 1 S.C.R. 1075.

55 Sonia Lawrence and Patrick Macklem, "From Consultation to Reconciliation: Aboriginal Rights and the Crown's Duty to Consult," Canadian Bar Review 79 (2000): 255.

56 Inman, Smis and Cambou, "We Will Remain Idle No More," 266.

57 "Fiduciary" is a person who holds a position of trust or confidence with respect to someone else. See Mary C. Hurley, The Crown's Fiduciary Relationship with Aboriginal Peoples. Law and Government Division of the Parliament of Canada, December 18, 2002, http://www.parl.gc.ca/content /LOP/ResearchPublications/prb0009-e.htm.

${ }^{58} \mathrm{R}$ v. Sparrow.

59 Michael Den Tandt, "Indian Act, Racist Relic of 1876, Should Be Abolished - And So Should Reserves," Canada.com, January 6, 2013, http://o.canada.com/2013/01/06/0107-col-dentandt/. 


\section{Idle No More}

The Idle No More protest movement was launched in response to the Jobs and Growth Act of 2012 and the 43-day hunger strike of Chief Theresa Spence of the Attawapiskat First Nation, who had declared a state of emergency in the Attawapiskat community in northern Ontario in 2011 because of a housing crisis. ${ }^{60}$

INM is a grassroots non-profit movement that has no political affiliation. The founders of the movement do not have the same mandate or identical goals as Indian band councils or the Assembly of First Nations. There is no formal connection between the AFN and the movement, even though Shawn Atleo (at the time National Chief of the Assembly of First Nations) expressed support for INM, which had generated a "tremendous outpouring of energy, pride and determination by our peoples," according to him. ${ }^{61}$ Thus, INM neither represents an official Aboriginal body, nor does it speak for all Native peoples.

On the other hand, the movement has over 6,000 followers on Twitter, it has obtained more than 135,000 "likes" on Facebook, and it is estimated that at a certain period its Facebook page had about million readers a week. ${ }^{62}$ This "unprecedented mobilization" of Indigenous peoples has increased public and media pressure on the federal government, and even forced an official meeting between Prime Minister Harper and a delegation of roughly 100 First Nations leaders, coordinated by the Assembly of First Nations and held on January 11, 2013.63 All these indicators suggest that the movement represents a powerful political voice of Indigenous peoples.

Idle No More promotes environmental protection, sustainable development, Indigenous sovereignty, and strives to educate both Native and non-Native people on these issues. It also calls for regular triangular meetings between First Nations leaders, the Government of Canada, and industrial companies in order to involve Aboriginal peoples in negotiations and decision making concerning legislation

60 "Timeline: Idle No More's rise Movement created out of opposition to measures in federal budget," CBC News, October 4, 2013, http://www.cbc.ca/news2/interactives/timeline-idle-no-more/.

${ }^{61}$ Andrea Nicoll, "Idle No More Movement Sweeping the Nation," The Oxbow Herald, January 26, 2013, http://www.oxbowherald.sk.ca/News/Regional/2013-01-26/article-3164612 /Idle-No-More-movement-sweeping-the-nation/1.

62 "Idle No More," Twitter profile of Idle No More, https://twitter.com/idlenomore; and "Idle No More," Facebook profile of Idle No More, https://www.facebook.com/IdleNoMore Community. See also Joe Friesen, "What's behind the Explosion of Native Activism? Young People," The Globe and Mail, January 18, 2013, http://www.theglobeandmail.com/news/national /whats-behind-the-explosion-of-native-activism-young-people/article7552791/.

63 Chris Hall, "Stephen Harper, First Nations and an Opportunity Lost," CBC News, January 11, 2013, http://www.cbc.ca/m/touch/news/story/1.1308543. 
affecting their communities. ${ }^{64}$ More specifically, they "call for Canada, the provinces and the territories to repeal provisions of Bill C-45 [...], abandon all pending legislation which does the same, deepen democracy in Canada through [...] consultation on all legislation concerning collective rights and environmental protections [...], affirm Aboriginal Title and Rights, as set out in Section 35 of Canada's constitution, [...] and honor the spirit and intent of historic Treaties."65

This "Call for Change" reflects the particular demands of First Nations. First, it calls for consultations with Indigenous peoples on legislation that concerns them. This demand is based on the right to "free, prior, and informed consent" that Idle No More derives from the UNDRIP, and from the Canadian Supreme Court's rulings, such as R v. Sparrow.

Second, the "Call for Change" mentions collective rights. These form part of Indigenous peoples' identity with their holistic approach. It therefore seems unlikely that First Nations would yield these rights, and would embrace for example private property, as favored by conservative scholars like Thomas Flanagan. Third, it invokes rights protected by Section 35 (1) of the Constitution of Canada, 1982, which include the right to self-determination.

The supporters of INM stress the resource-oriented approach to land and environment of the Harper Government. They argue that legislative changes of the Conservative Government pursue predominantly priorities set out by the Conservatives such as the maximum financial efficiency and exploitation of natural resources. They consider protecting ethnic and cultural diversity less important. ${ }^{66}$ For this reason, members of Idle No More call on all people "to join in a peaceful revolution, to honor Indigenous sovereignty, and to protect the land and water. INM has continued and will continue to help build sovereignty and [...] to pressure government and industry to protect the environment." 67 Here the movement endorses environmental protection, which is, however, far down on the list of neoliberal priorities of the federal government. As Gabrielle Slowey explained, "Neoliberalism's ideal citizen is the individual who competes in the marketplace, is self-reliant, and does not act as a drain on the state. Thus, from a neoliberal

${ }^{64}$ Benjamin Shingler, "Idle No More: First Nations Activist Movement In Canada Revs Up For Week Of Rallies," The Canadian Press, December 16, 2012, http://www.huffingtonpost.ca/2012/12/16 /idle-no-more_n_2312001.html.

65 "Calls for Change," official website of Idle No More, www.idlenomore.ca/calls_for_change.

66 Russel Diabo, "Harper Launches Major First Nations Termination Plan: As Negotiating Tables Legitimize Canada's Colonialism," official website of Idle No More, June 16, 2013, www.idlenomore.ca /harper_launches_major_first_nations_termination_plan_as_negotiating_tables_legitimize _canada_s_colonialism.

67 "Vision," official website of Idle No More, http://www.idlenomore.ca/vision. 
perspective, the ideal First Nation is an independent First Nation that competes in the marketplace and is independent of the state. And from a Canadian neoliberal perspective, an ideal First Nation would be one that does not impede resource development activity." 68

Slowey's argument also implies that the main difference between the demands of the Idle No More movement, and by extension of the entire community of Aboriginal peoples, to enforce their right to self-government, and the reforms of the Harper Government is not the state the two groups want to achieve, but rather the way of how they want achieve it.

Critics of the movement, such as Sadeq Rahimi and Mark Milke, liken Idle No More to the Arab Spring. They argue that the movement does not have a strong and qualified leader who would be able to discuss legislative changes with the government. More importantly, they deplore that supporters of Idle No More do not have a uniform opinion on how to reform the Indian Act and improve the plight of Aboriginal peoples. Furthermore, these critics of INM defend the Harper Government's legislation, asserting that it will not allow for reserve land to be sold off to non-Aboriginal buyers, but on the contrary, it will allow for First Nations to lease more land in order to create housing subdivisions and commercial complexes. Thus, Indian reserves and their residents will be able to benefit from the cash flow. ${ }^{69}$

The rhetoric of these critics of Idle No More is strikingly reminiscent of Flanagan's when they identify the rural nature of Aboriginal communities living on collectively owned land in the twenty-first century as a major problem..$^{70}$ This view is distorted, Eurocentric and urban. Arguing that Harper's legislation enabled First Nations to lease land for the construction of modern industrial complexes and shopping centers, points to the one-sidedness of such reasoning as it addresses only the narrowly defined economic aspects of the recent legislation.

In January 2013, Aboriginal Affairs Minister John Duncan and several other government officials invited a delegation of First Nations chiefs to Ottawa to discuss the demands raised by Idle No More. Harper eventually attended the whole meeting, despite his original intention to attend only a part of it. ${ }^{71}$

${ }^{68}$ Gabrielle A. Slowey, Navigating Neoliberalism: Self-Determination and the Mikisew Cree First Nation (Vancouver: UBC Press, 2008), 15.

69 Sadeq Rahimi, "Canada Heading for Bloodshed, Warns Aboriginal Leader," The World Post, January 15, 2013, http://www.huffingtonpost.com/sadeq-rahimi/canada-heading-for-bloods_b_2474733 .html.

70 Ibid.

71 Hall, "Stephen Harper, First Nations." 
Despite the promises that the meeting was only the beginning and would be followed by similar events, to date no meetings similar in scale have taken place. Furthermore, Stephen Harper stated that "people have the right in our country to demonstrate and express their points of view peacefully as long as they obey the law, but I think the Canadian population expects everyone will obey the law in holding such protests." 72 His statement gives the impression that the Aboriginal resistance expressed in Idle No More and the Indigenous resentment toward his policies did not significantly put him out of countenance.

Idle No More lost its momentum after a series of nonviolent actions that prompted the official meeting between representatives of the federal government and the delegation of First Nations chiefs. The round dances stopped, the rallies were disbanded and the media moved on to other topics. ${ }^{73}$ However, some representatives of Indigenous peoples like Federation of Saskatchewan Indian Nations Chief Jonathan Kimberly, scholars like John Ralston Saul, a prominent Canadian author, essayist and proponent of rights of Indigenous peoples, and even some federal officials believe that similar projects may follow Idle No More in the future. ${ }^{74}$

Saul is confident that the formation of the Idle No More movement means that there is a new elite of Indigenous peoples with college diplomas that is and will be gaining strength and increasing its influence. Most of the INM's activities such as flash mobs and teach-ins were peaceful. Saul argues that without a change in stances of non-Aboriginal Canadians who prevent Indigenous peoples from regaining their rights and returning to power this elite might instigate riots which could have worse consequences than those of the railroad blockades and demonstrations of INM. ${ }^{75}$

Idle No More was a backlash against the Conservative Government's legislation affecting the rights of Indigenous peoples, passed without consultation with Aboriginal peoples. Idle No More was able to mobilize thousands of people for

72 “9 Questions about Idle No More," CBC News, January 5, 2013, http://www.cbc.ca/news/canada 19-questions-about-idle-no-more-1.1301843.

${ }^{73}$ Joe Friesen, "John Ralston Saul Calls for All Canadians to Be Idle No More," The Globe and Mail, October 31, 2014, http://www.theglobeandmail.com/news/national/john-ralstan -saul-calls-for-all-canadians-to-be-idle-no-more/article21415062/.

${ }^{74}$ Tyler Clarke, "Idle No More Was Only the Beginning," West Coast Native News, December 16, 2014, http://westcoastnativenews.com/idle-no-more-was-only-the-beginning/; and Benjamin Shingler, "Emails Show Federal Officials Worried About Second Idle No More Movement," The Canadian Press, August 17, 2014, http://www.ctvnews.ca/politics/emails-show-federal-officials-worried -about-second-idle-no-more-movement-1.1963194.

75 John Ralston Saul, "The Resurgence of Indigenous Power," commentary on The Comeback, thestar. com, official website of John Ralston Saul, http://www.johnralstonsaul.com/. 
action. ${ }^{76}$ Despite Harper's seemingly little interest in these events, the movement also prompted an official meeting between representatives of Native peoples and the government. The movement did not accomplish big goals as Bill C-45 is still applicable. It lost momentum in a relatively short period of time; however, the fact that Aboriginal issues got into the forefront of public and media interest was a success on which Indigenous peoples can built in the future.

\section{Conclusion}

Despite the extensive financial support that they receive from the State, First Nations are still very poor. The Indian Act of 1876, along with the Constitution of Canada, 1982, has provided for a special status of First Nations within Canada and guaranteed the preservation of their distinctiveness, in particular through their collective rights, for almost 140 years. On the other hand, it has effectively isolated First Nations in the dysfunctional system of reserves and a detrimental dependence on social welfare. Thus, there is a consensus that reform and an eventual replacement of the Indian Act of 1876 are needed. However, the Harper Government and First Nations have different ideas of what direction this legislative change should take.

As is evident from the demands of the Idle No More protest movement, and from the official statements of the AFN, First Nations communities believe that the government has to introduce new legislation in which the Aboriginal rights to self-determination will be guaranteed before the Indian Act can be replaced. However, there are very different conceptual approaches of how to treat the question of self-determination and self-government of Indigenous peoples.

First Nations base their right to self-determination on several assumptions. First, they believe it is one of the rights that are legally guaranteed to Aboriginal peoples by Section 35 (1) of the Constitution of Canada, 1982, and by the UNDRIP endorsed by Canada in 2010. Second, First Nations claim their right to self-government, which represents an integral part of self-determination. One of the possible ways in which this can be put into practice is through self-government agreements. More than twenty self-government agreements have already been concluded between First Nations bands and the federal government.

As of now, the long-term effectiveness of these agreements is impossible to know. The problem is that the process of submission and negotiation of the SGA is lengthy and complex. Furthermore, important policy areas remain under federal

76 "Cree Walkers Meet Minister at End of Idle No More Trek," CBC News, March 25, 2014, http://www .cbc.ca/news/canada/ottawa/cree-walkers-meet-minister-at-end-of-idle-no-more-trek-1.1392239. 
jurisdiction exclusively. However, both have potential. They meet the First Nations' claim for self-government and also transfer responsibility for the functioning of these Native communities into the hands of their own members, and thus ease the burden of the federal government.

The catch lies in the fact that the Conservative Government has been moving away from the term "self-government" to "governance" which implies that it has been replacing negotiations of self-government agreements, understood despite all their shortcomings as a practical assertion of Aboriginal inherent rights, with "sector-specific agreements." 77 This shows how different the perspectives of the Harper Government and Canadian Aboriginal peoples on the transformation of Indigenous-state relations, and the ways to enforce Aboriginal self-government, are.

Third, First Nations base their right to self-determination on the interpretation of the "fiduciary" relationship between the Crown and Aboriginal peoples and the doctrine of "free, prior, and informed consent." According to recent rulings of the Supreme Court of Canada, the fiduciary relationship is enshrined in Section 35 (1) of the Constitution of Canada, 1982. Such an interpretation, which implies the Aboriginal right to "free, prior, and informed consent" of Aboriginal peoples about their own affairs, should in practice ensure participation of First Nations in the preparation of legislative changes that directly affect them. However, the Harper Government has simply disregarded this legal doctrine - in effect violating the law of the land that its members swore to uphold.

Since 2006, Prime Minister Stephen Harper has personally met with representatives of Indigenous peoples only a few times. Moreover, concerning most of the legislative proposals, representatives of Indigenous peoples were not consulted. Bill C- 45 is the most visible example of the Conservative Government's circumvention of First Nations' consent when creating policies regarding their communities. Furthermore, the emergence of the Idle No More protest movement in response to the enactment of Bill C-45 shows how much Harper's policy differs from Aboriginal peoples' perspective.

The Harper Government prefers reforms of the Indian Act in order to achieve economic sustainability of the First Nations communities managing their own affairs. Harper's policies are based on a similar approach to the one proposed by Thomas Flanagan, who was Harper's advisor on Aboriginal issues. They believe that, instead of living on state aid, which annually forms a considerable part of the government's budget, Indigenous peoples should adopt a market based economy with all its aspects. In their opinion, it is necessary to eliminate collective

77 Papillon, “The Rise (and Fall?)," 126. 
ownership on reserves and introduce private ownership. ${ }^{78}$ Indigenous communities should also be financed from taxes collected from their own people. Finally, Aboriginal land, which is so valued and protected by First Nations, should be opened up for industrial companies, especially for the extraction and transportation of oil.

In conclusion, the visions that the Canadian First Nations and the Conservative Government have for the future legislative anchoring of First Nations, and more generally for all Aboriginal peoples in Canada, do not share enough elements to find common ground. Although there is a consensus that the reform of the Indian Act is needed, and that Native peoples should be responsible for their own affairs, views on the way of achieving this differ. While one side speaks about collective rights, the right to free, prior, and informed consent, sustainable development, and the distinctiveness of Indigenous peoples, the other side stresses the importance of a market based economy focusing on self-sufficiency, private ownership, and further natural resource exploitation requiring a substantial decrease in government protection.

The reform of the Indian Act of 1876 and the improvement of the dismal situation of First Nations in Canada can be successfully carried out only under the condition that the two sides cooperate. Such cooperation, however, seems difficult to carry out due to their conflicting views on the matter. In addition, for such cooperation it would be necessary for the Conservative Government to show signs of efforts to involve First Nations in negotiations on policies that affect them which it has not yet shown.

This basic problem of the future status of First Nations in Canada in relation to the Canadian government was perfectly expressed by Derek Inman, Stefaan Smis, and Dorothée Cambou: "In an effort to accommodate Aboriginal peoples, to reconcile past injustices, and to respect the honor of the Crown, the Canadian government should have at least consulted with the Aboriginal peoples prior to rushing through Bill C-38 and Bill C-45. Maybe this is why the Aboriginal peoples of Canada stood up and refused to be Idle No More."79

\section{Biographical Note}

Kristýna Onderková is a graduate of Charles University in Prague. She works as a paralegal in one of leading Prague law firms and specializes in Canadian law and politics.

E-mail: onderkova.k@gmail.com

\footnotetext{
78 Flanagan, First Nations, 198.

79 Cambou, Inman, and Smis, "We Will Remain Idle No More," 285.
} 